Agnieszka Pęska*

\title{
The Role of the Surveyor in Real Estate Delimitation Run during Administrative and Court Procedure
}

\section{Introduction}

In the present time, when real estate belongs to the most valuable goods, it is extremely relevant to precisely demarcate the location of boundaries - the range of ownership between neighbouring real estates. One way to protect that law is the delimitation of real estate procedure, which by demarcating real estate legal boundaries stands for the solution for existing boundary controversy and helps to maintain proper relationships with neighbours.

Although the real estate delimitation problem originates from the right of ownership (civil law), it also reaches public administration issues, performed by public administration authority as part of its tasks. Boundaries location demarcation activities became regulated by legislator in precedented way, as a two-stage procedure consisting of administrative proceedings and depending on the former's result legal proceedings.

Real estate delimitation is a complex and reluctantly performed work by surveyors. Apart from good knowledge of geodesic, cartographic, administrative and civil regulations, surveyor must represent proper mediating skills, in order to end long-term boundary controversy between neighbours. It is often his knowledge, experience and behavior what matters most during boundary trials and in consequence decides upon a delimitation result.

\section{Delimitation Essence}

As indicates Rudnicki in [7] the need for real estate delimitation rises, when grounds boundaries were not demarcated or became questionable and there is

* AGH University of Science and Technology, Faculty of Mining Surveying and Environmental Engineering, Krakow, Poland 
no opportunity for restoration of boundary monuments. He states: “Delimitation consists in distinction of real estate from other corralling grounds by demarcating in field the line defining the range of ownership in relation to neighboring grounds".

The most important definition for surveyors is contained in Art. 29 of the Act of 17 May 1989 - Geodetic and Cartographic Law [10], which states that the aim of real estate delimitation is to demarcate the course of its boundaries by defining the position of points and boundary lines, fixing these points by boundary monuments in the field and compiling proper documentation. Subject to delimitation, if and when needed, are either all or some boundaries of given real estate along with adjacent real estates or other grounds.

It seems that the most correct definition of delimitation was proposed in [3], indicating that: "Real estate delimitation is the set of law and measurement procedures demarcating the boundary points location of cadastral parcel which is a land property, in case when they do not define the law boundary and necessary documentation, being the ground for law proceedings, indicating, that stated boundary points define the law boundary".

Worth mentioning is also the Supreme Court's decision of 10 September 1997 [6], in which was underlined, that, "it is not the goal of delimitation proceedings to demarcate all boundaries of given real estate, in such manner, its area matches the content of register", what is often anticipated by parties to proceedings.

\section{Law Regulations}

According to geodesic and cartographic law [10] regulations, real estate delimitation may be proceeded in two separate ways: by means of administrative proceedings (where the competent authority is a mayor or mayor of the city) and legal proceedings in front of the common court.

Rule implementing for previously mentioned act is Ordinance of Ministers of Internal Affairs and Administration and the Agriculture and Food Economy on April 14, 1999 on the real estate delimitation [8], which specifies the types of documents which are the basis for demarcation location of boundaries and also the way the surveyor performs activities concerning the course of boundaries demarcation and documentation preparing during real estate delimitation.

Geodesic and cartographic law regulations does not describe in all-embracing manner the course of administrative proceedings. According to the Supreme Administrative Court, all the inaccuracies pertaining to lack of proper regulations should be solved in accordance with Code of Administrative Proceedings [12].

In case, when administrative proceedings are not settled, the case is devolved to court and from now on it is resolved during legal proceedings in front of the 
common court, on the basis of the Civil Code [11]. Real estate delimitation is a law institution described in the second part of the Civil Code "Ownership and other Real Rights". The Civil Code records in an unambiguous manner defines the neighboring lands owners duties, concerning both: maintaining permanent boundary monuments and proceedings in case of these monuments become the subject to dispute. It also indicates the necessity for both parties to participate in all costs pertaining to boundary monuments maintaining and delimitation.

\section{Real Estate Delimitation in Administrative Proceedings}

Administrative proceedings for delimitation are with some exceptions the very first and obligatory procedures. The main stages of the procedure along with participating entities are presented in Figure 1.

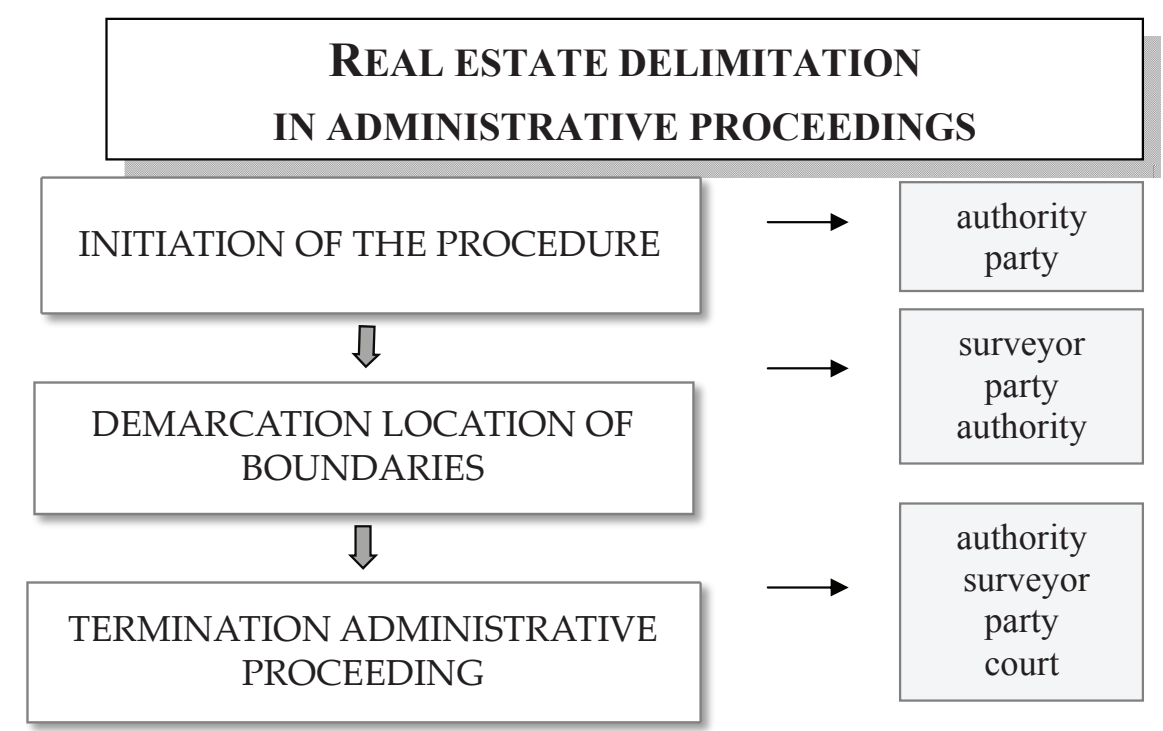

Fig. 1. Main stages of real estate delimitation and participating entities

\subsection{Delimitation Procedures Initiation}

The delimitation procedures initiation is regulated by Art. 30 of the Geodesic and Cartographic Law. This procedure must be began in formal way. In other words it must be initiated in accordance with Art. 61 of Code of Administrative Procedure [9]. Commune administrator, (mayor or mayor of the city) performs a real estate delimitation at the request of a party or of its own motion. 
The precondition for real estate delimitation proceedings initiation at the request of a party might be:

- a boundary controversy concerning the course of boundary line between the owners (holder of perpetual usufruct) of neighbouring properties,

- effaced boundaries rising doubts pertaining to its course,

- discrepancy between law and actual states.

According to the contents of Art. 30 paragraph 4 of Geodesic and Cartographic Law, procedure initiation occurs in form of resolution, which cannot be appealed. Being formal, the day of the proceedings initiation means the day of delivering the resolution to the parties.

On the basis of Art. 30 paragraph 2 of Geodesic and Cartographic Law, there are following cases during which it is possible to perform delimitation proceedings of its motion to be singled out:

- during the consolidation and exchange of lands,

- if there is no parties request but national economy needs or social interest justify delimitation.

As it is indicated in article 31 paragraph 1 of Geodesic and Cartographic Law, boundaries demarcating activities in delimitation proceedings are performed by a surveyor authorized by the mayor or mayor of the city. An authorized surveyor should own second range certified surveyor's qualifications: "delimitations and real estate (lands) division and law oriented documentation preparation". In law regulations there is no record letting the parties choose the surveyor to perform boundaries demarcating activities. Consequently, it seems right for municipal body to make a choice by means of selecting the best offer during tender.

Instructive example could be situation of surveyor from Świętokrzyskie region, who made an agreement with a party requesting for delimitation, concerning performing coverage for proceedings in front of municipal body. Agreement contained notation proving that ordering person was aware of the role of surveyor in delimitation proceedings and also there was explicitly stated that the condition for correct procedure terminating was to receive positive opinion from community and consequently leave documents in geodetic and cartographic documentation center. Regardless of meeting both conditions, unhappy with the result of delimitation client refused to pay the salary for the work. Surveyor took proceedings against his client but on December $12^{\text {th }}, 2012$, the judgment from provincial court in Kielce stated: "[...] surveyor performing boundaries demarcation in delimitation proceedings is not an entity acting on 'private' behalf of parties of delimitation proceedings. From that very same reason, in administrative proceedings concerning real estate delimitation, parties cannot make any separate agreements, nor subcontract to third parties activities related to proper 
authority" [5]. According to judgment from Provincial Administrative Court in Warsaw from September $2^{\text {nd }} 2008$ [14]: “[...] authority responsible for delimitation should subcontract actions to surveyor, pay him, and then to share the costs in half between the parties [...]. In described situation accurate is the allegation concerning agreement nullity as it was made with purpose of obeying the law (Art. $58 \S 1$ Civil Code)". Summarizing, there is no possibility to perform delimitation proceedings out of scope of administrative and legal procedures, described in Geodesic and Cartographic Law.

\subsection{Demarcation Location of Boundaries}

Actions related to real estate delimitation are initiated by surveyor by reporting geodesic work to the appropriate centre of geodesic and cartographic documentation. Collected documents should be put into quality analysis and also be checked in terms of usage possibilities in proceedings. Reliability and quality must be investigated by means of a comparative analysis of collected documents concerning real estate, boundary monuments and segments of boundary lines.

As an example of correctly performed documentation analysis might be presented real estate located in Suchowola in Osiek community. From geodesic and cartographic documentation center, contractor received among other things: drafts from subdivisions of real estate performed by two different contractors in 1995 and 1996. Measurements were done on the basis of geodetic control network, located along the road adjacent to parcel south boundaries. During the analysis of these documents, after calculating coordinates for boundary monuments in parcels $1252 / 6$ and 1253/5, it occurred, that there are blatant differences between boundary courses defined in both cadastral documents. From several-meters discrepancies in the case of the boundary of parcel 1252/6 with the road 1010/3, to almost one meter discrepancy in boundary section being a subject to delimitation. The map depicting the situation in the ground state background was presented in Figure 2.

Both cadastral documents concerning real estate subdivision were accepted in geodetic and cartographic collection of documents, what rises the questions about documentation review made by surveying company adopted by geodetic and cartographic documentation centre. Thought-provoking is also the boundary line location passing through the buildings.

Having performed the analysis which showed relevant discrepancies in gathered documentation, the surveyor could not indicate the course of boundaries between properties on the field because of the two equivalent documents. Consequently, he could only point two equally probable possibilities for the course of boundaries. The surveyor, who was preparing to perform that delimitation, came up with conclusion that the solution for the procedure could be consistent statement from parties or boundary settlement, which legitimizes the course of the boundary in zone stated by divergent boundaries from divisions. 


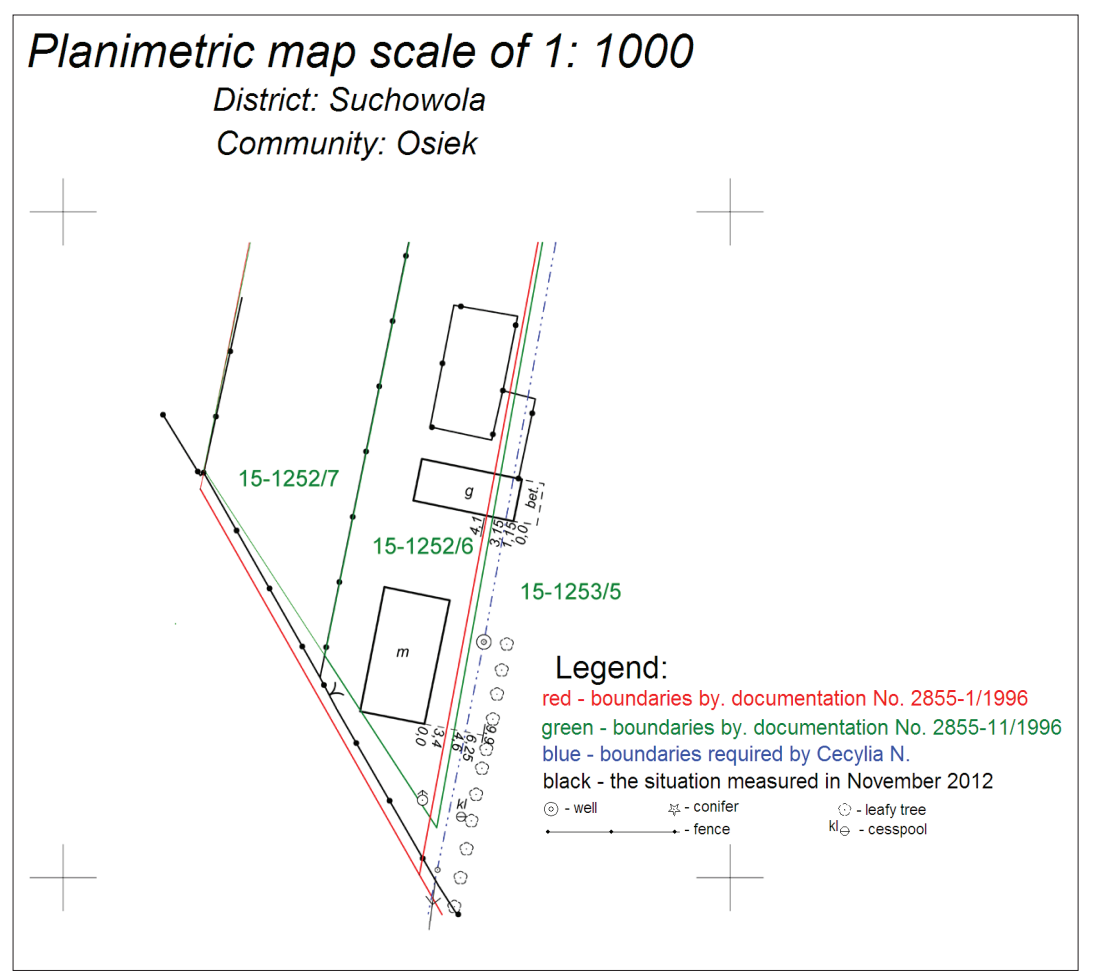

Fig. 2. Planimetric map fragment with real estate boundaries

Source: self elaborated on the basis of measurement documentation

Having finished the analysis of existing documentation, the surveyor performs site reconnaissance in order to [8]:

- find boundary monuments,

- define the location of moved, damaged or destroyed boundary monuments and boundary points, if only documents necessary to define that location exist.

The provisions of the regulation on the delimitation of real estate oblige the surveyor to indicate the date of hearing and to deliver to the parties the summons to appear on the ground. Surveyor works on behalf of administration authority and with its authorization signs the summons. Consequently, all his actions must be consistent with Code of Administrative regulations in area of summons [9]. Summonses are delivered to parties not later than 7 days before the date of boundary trial.

Relevant issue is contained in Art. 32 paragraph 3 Geodetic and Cartographic Law, which states that unjustified non-appearance of correctly summoned party doesn't suspend surveyor's actions. 
In the case of justified non-appearance the surveyor suspends his actions until the obstacle disappears, however, for not longer than a one month period.

- Regulations from chapter 6 of Geodetic and Cartographic Law, and executive regulations for that act, define the rules of the delimitation proceedings, but do not reserve the form of its course. Regulations context, however unambiguously indicates that for those actions the form of administrative trial is dedicated [2].

- According to regulations [8] and the boundary protocol and settlement contents, which are enclosed to geodesic and cartographic law, we can point out the following actions performed by the surveyor during boundary trial on ground:

1. case induction,

2. verification of presence and identity of parties,

3. the subject of the case introduction,

4. parties statement collection concerning collected evidence,

5. site recoinnassence,

6. the course of boundaries demarcation,

7. trial closure.

The most important stage of ongoing evidence taking is real estate boundaries course demarcation, which according to records [10], may occur on the basis of:

- existing monuments and boundary traces, maps and other documents,

- consistent parties statements,

- settlement made in front of surveyor.

When after the performed analysis and site reconnaissance it is possible to demarcate the boundaries on the basis of collected documentation, the surveyor informs the parties and then indicates the course of the boundary, performs the monumentation, creates the boundary protocol and makes measurements of boundaries and permanent elements of land development relevant in terms of the location of boundary demarcations.

Such course of evidence taking comes down to surveyor performing materialtechnical actions, which is ended with boundary protocol writing. Boundary protocol in its essence doesn't end the proceedings, but states as en evidence of case factual state determination and is the basis for administrative authority assessment ratifying the boundaries [2]. Consistent with judgment of Supreme Administrative Court [13], circumstances relevant in terms of case resolving, have evidential value only if were consolidated by administrative authority in form of protocol [12].

In Łagiewniki village, Busko-Zdrój community, on October $5^{\text {th }}, 2012$ was initiated the proceeding concerning delimitation between cadastral parcels 392/2, 393/1 and 393/2 with parcels 390, 391 and 394 (Fig. 3). In Geodesic and Cartographic Documentation Centre in Busko-Zdrój among other things there was document (no. 248-10/124/57) prepared in 1957 as the part of work related to land and building registration establishment, in which there was data allowing to indicate the course of 
boundaries. During site reconnaissance there wasn't any boundary monuments of these real estates found. What was found is minor control point no. 1 (current number 5001/20), which coordinates discrepancies transformed from local coordinate system of Busko-Zdrój city to 2000 coordinate system measured in field equaled $0.09 \mathrm{~m}$.

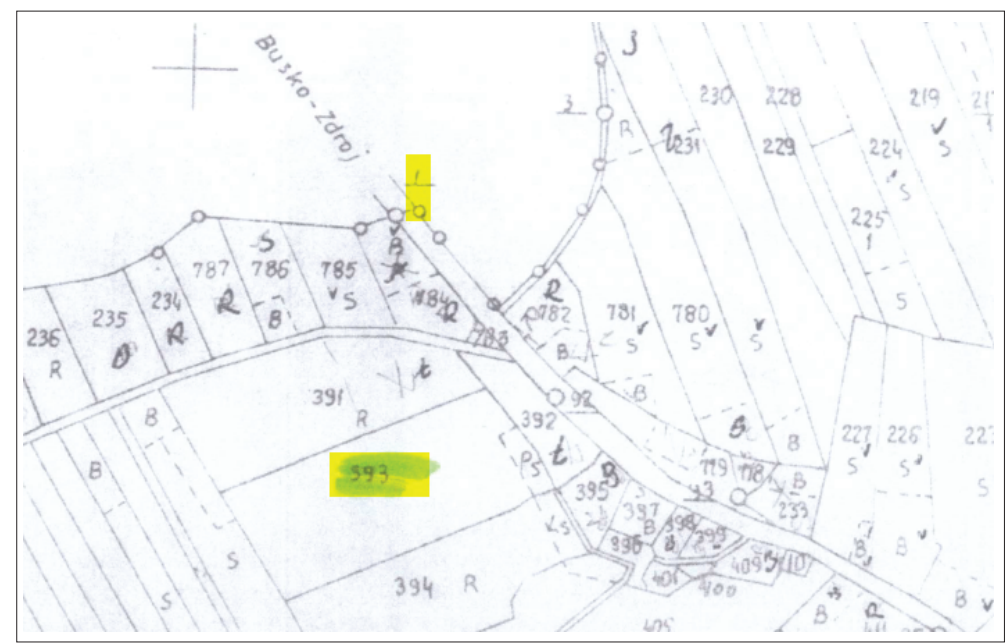

Fig. 3. Cadastral fragment map with parcel location and minor control points Source: own study on the basis of gathered documentation

On the basis of available field sketches (Fig. 4) basic sketch was prepared, which fragment was presented in Figure 5. Using coordinates listings and measures included in basic sketch, boundary points coordinates were calculated. Boundaries outlined in that manner were presented to parties during boundary trial and was accepted by them.

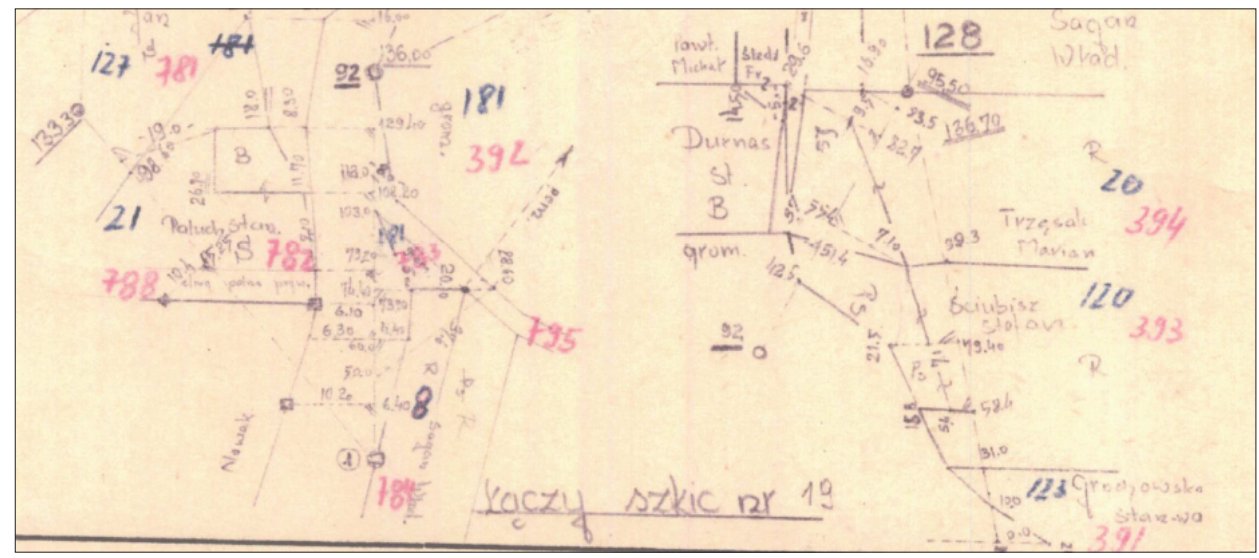

Fig. 4. Field sketch fragment from 1957

Source: Geodesic and Cartographic Documentation Center in Busko-Zdrój 


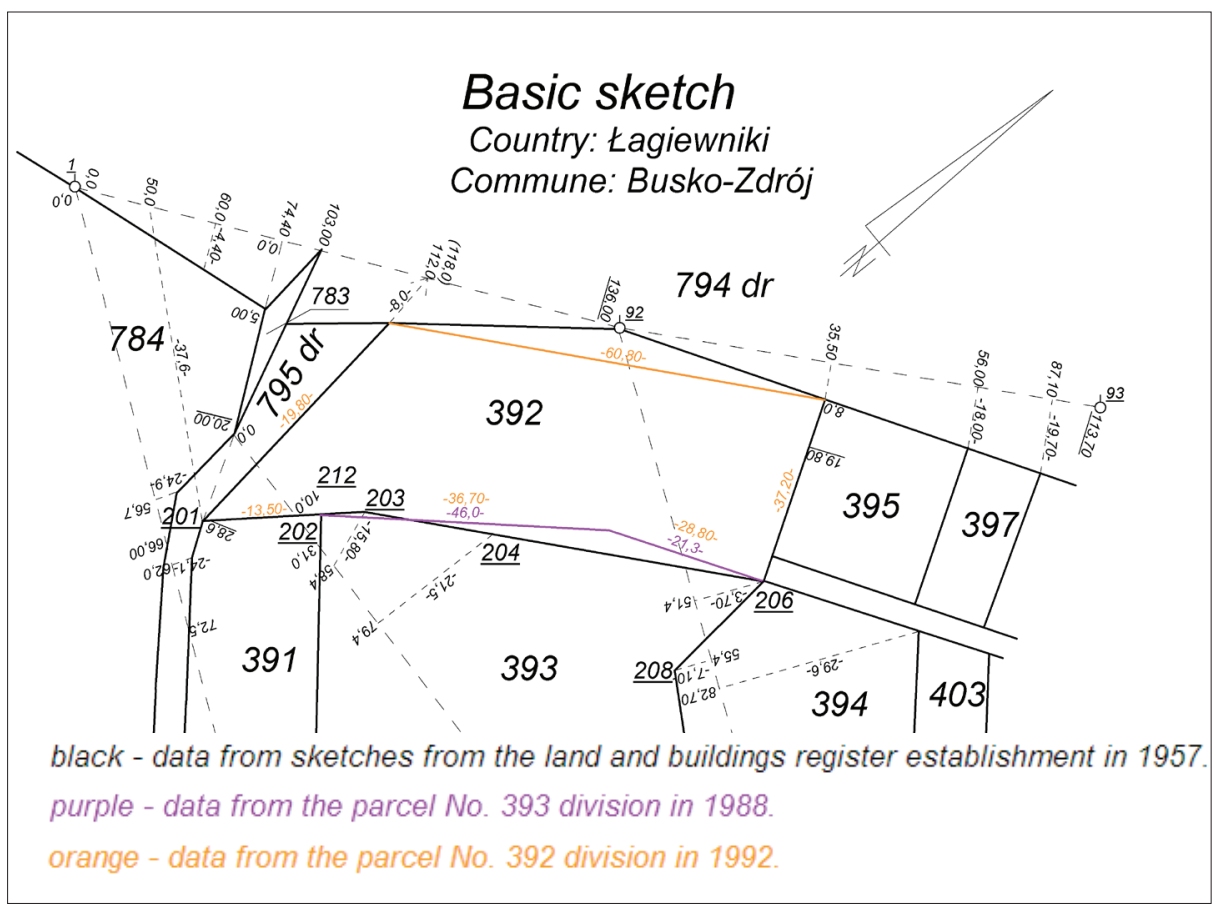

Fig. 5. Basic sketch fragment

Source: own study on the basis of measurement documentation

Other case occurs, when during boundaries course demarcation actions surveyor notices:

- lack of boundary monuments ant traces, maps or other documents letting the course of boundaries reproduction,

- discrepancies in documents,

- discrepancies between law state and factual state on ground.

In this case he is obliged to explain the actual situation to the participants of proceedings, and then he pleads for consistent indication of the course of boundary. In described situation, real estate owners are obliged to cooperate during real estate delimitation [11]. As consistent indication of parties is also interpreted situation when one of parties indicates the course of boundary, and the second one didn't give out the declaration, but at the same time is not questioning the indicated course.

If the boundary controversy occurs, the surveyor is obliged to encourage parties to make a settlement [10]. Boundary settlement is a particular proceeding binding administrative procedures with civil law regulations.

If during boundary trial there is no settlement and parties remain in boundary controversy, and on the basis of the documents there will not be possible to 
determine the course of the border, the surveyor is required to temporarily mark and measure the boundaries indicated by the parties, determined by the contents of the documents, specifying the last peaceful state possession or consistent with the state on the ground [10]. From actions performed in that manner boundary protocol is performed and presented during actions on ground or resulting from documentation course of boundaries variants are marked on boundary sketch.

The final element is to develop an opinion on the borders of the real estate, which in accordance with Regulation [8], should include:

- assessment of the proper conduct of the boundary indicated by the parties, identified on the basis of documents, running according to the last peaceful state possession or existing on the property,

- description of the border proposed by land surveyor, together with the reasons.

All prepared documents shall be transferred to the competent mayor (president of the city). This authority shall discontinue administrative proceedings and hands the matter over ex officio for consideration to the court.

The formal end of the boundary trial should be preceded by reading out the written boundary recognition agreement or act of the settlement to the participants of the proceedings by the surveyor. Before signing the protocol, parties have the right to submit comments and objections regarding its content, and may also request for the amendments and the inclusion of protocol documents which they believe as relevant to the case. After completion of the boundary trial it is not acceptable to supplement the content of the protocol, even if it would involve straightening typos or other obvious mistakes [2].

The surveyor, when closing the trial shall inform the parties about the further course of the administrative procedure, depending on the result of operations conducted on the ground. On the basis of performed activities, the surveyor prepares documentation consisting of two parts: the documentation of real estate delimitation and technical documentation. After a positive opinion on the proceeding correctness by the authority conducting the proceedings of real estate delimitation, documentation shall be deposited in the geodetic and cartographic documentation center in order to adopt it for geodetic and cartographic collection of documents.

\subsection{Completion of the Administrative Procedure}

After verification activities, in the course of which no abnormalities were noticed, the competent authority shall issue a decision in the real estate delimitation proceeding. Figure 6 shows a diagram illustrating the types of decisions issued with regard to the completion of the administrative proceedings depending on how the boundary trial ends. 


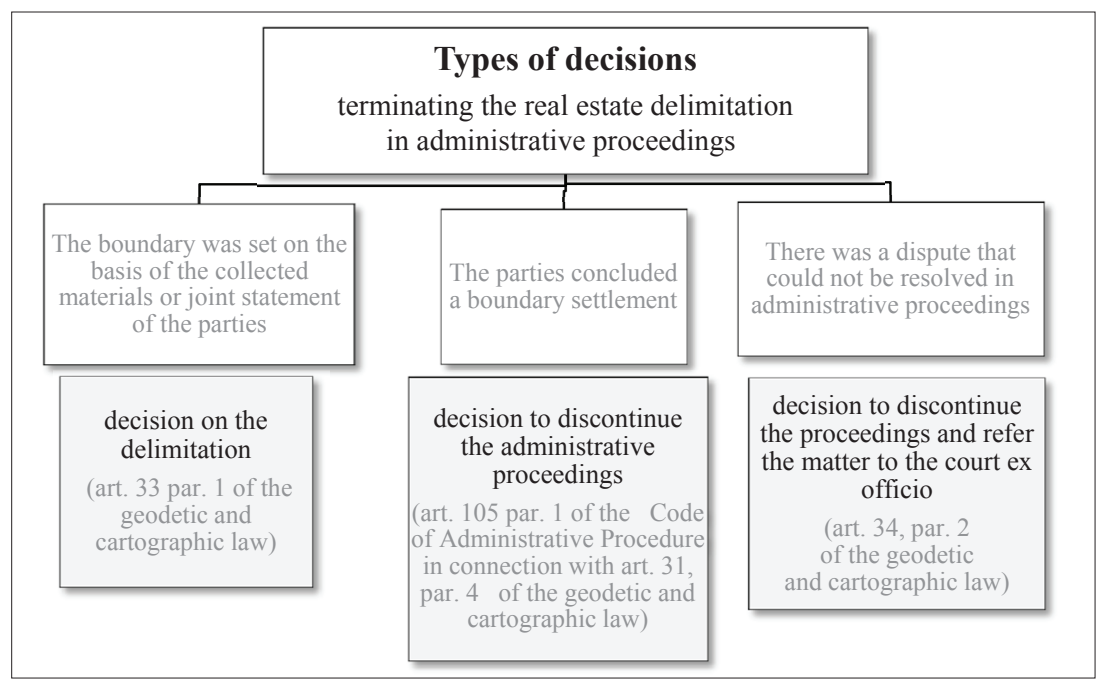

Fig. 6. Various types of decisions terminating the real estate delimitation in administrative proceedings

\section{Real Estate Delimitation in Legal Proceedings}

Legal proceedings in area of real estate delimitation may occur in the following cases provided in the Geodesic and Cartographic Law:

- when in front of the court the case of property or for release of real estate is under way, to settle the case determining of the course of boundaries demarcation is needed;

- If the local government conducting the proceedings delimitation discontinued the proceedings, due to lack of grounds for the decision on the delimitation of the real estate, or if in the case of a dispute as to the course of the boundary lines settlement is not achieved;

- when the party is dissatisfied with the delimitation of the border during the administrative procedure requested within 14 days from the date of notification of the decision in this case, transfer the case to the court.

Court proceedings in cases of delimitation of real estate is a derivative of ineffective administrative proceedings and there is no legal possibility for conducting delimitation procedure directly before the court, bypassing the administrative procedure. The exception is described in [10], concerning the pending case of ownership.

Competence to carry out a case of delimitation has local jurisdiction district court, seized of the case, as a court of first instance. As noted Durzyńska [1] a common court shall consider a case referred to it from the beginning and is not bound by the findings 
made by the administrative authority, does not apply also to the decision resulting in the administrative procedure. Refer the case to the court by the administrative authority running the procedure takes place ex officio. All documentation gathered in the administrative proceedings shall be forwarded to the competent court [7].

The case of the real estate delimitation before a common court goes under the provisions of substantive civil law, and in the procedure - based on the provisions of the Code of Civil Procedure, speaking of non-litigious proceedings [1]. According to [10], the court shall consider the case of real estate delimitation in non-litigious proceedings. It may be terminated conclusion of a court settlement by court order or dismissal of the application. The court's decision is actionable in the normal course of the proceedings. The criteria for determining the borders of which the court may make a delimitation the real estate, are contained in the records of the Civil Code [11], which says: "If land boundaries are disputed and the legal status cannot be determined, the boundaries are established as at the last peaceful possession. If such a peaceful possession cannot be determined either, and delimitation proceedings do not result in an agreement between the parties concerned, the court will fix the boundaries taking all circumstances into consideration; it may at the same time award one of the owners an appropriate additional payment of money".

On this basis it can be concluded that the activities of delimitation of real estate, the court shall take into account:

- the legal status of the property,

- the last peaceful state ownership,

- any other circumstances.

The role of the surveyor in the judicial proceedings for the real estate delimitation takes a different form than in administrative proceedings. In court proceedings the surveyor acts as a court expert in the field of geodesy and cartography, and his opinion is the evidence in evidential proceedings regulated by the Code of Civil Procedure.

The primary responsibility of an expert is to draw up an opinion based on the research. In addition, expert responsibilities include other activities which, according to the decision of the judicial body, have been commissioned by person with specialized knowledge.

These duties may include [4]:

- compulsory attendance on the court summons;

- obligation to participate in the taking of evidence;

- obligation to provide preliminary consultations;

- obligation to submit an oral opinion at the trial, if the determining authority considers it necessary, despite the prior submission of a written opinion;

- duty to ask questions to the parties and witnesses, in the case when the expert expects to get in this way material needed him to deliver an opinion;

- obliged to respond to the questions of the judge and the parties. 
As emphasized in [4], the choice of an expert is always (under Polish procedural rules) in the competence of the court. This also applies when an expert is appointed at the request of parties to proceedings - the court is not bound by these proposals and only he has the authority to decide on the final selection of an court expert.

\section{Conclusions}

Delimitation of real estate is an important legal institution, allowing for the protection of property rights, by defining its range. Once initiated, proceedings for the real estate delimitation, must find its solution. It can occur in administrative proceedings, or in special cases when non-litigious proceedings in court. Legal boundaries, determined by an administrative or court decision, guarantee stability boundaries, and if they re-blurring, the ability to seamlessly indication.

In the procedure of delimitation of real estate surveyor is an irreplaceable person. In the course of the proceeding it occurs in a number of roles, all of which can be distinguished function:

- representative of the public administration, conducting the proceedings of the delimitation of real estate;

- a person having specialized knowledge in the field of geodesy and law, confirmed by certified surveyor's qualifications;

- the mediator, trying to solve the existing boundary controversy;

- quasi-judge, deciding whether there are reasons to finish the dispute as a result of the settlement, having the power of a court settlement;

- in judicial proceedings - court expert in the field of geodesy and cartography, whose opinion is an independent evidence.

The work of surveying, especially those related to property rights and the determination of its range seems to be invaluable experience for surveyor, supported by still incremented resource of knowledge. Delimitation of real estate requires from the surveyor also high psychological resistance, due to the high emotions of the parties during the boundary trial.

\section{References}

[1] Durzyńska M.: Rozgraniczenie i podział nieruchomości. LexisNexis Polska, Warszawa 2009.

[2] Felcenloben D.: Granice nieruchomości i sposoby ich ustalania. LexisNexis Polska, Warszawa 2011.

[3] Hanus P., Hycner. R., Kwartnik A.: Analiza terminologiczna wybranych problemów katastru izagadnień pokrewnych. Geodeta: Magazyn Geoinformacyjny, nr 10, 2013, pp. 15-22 (cz. 1), nr 11, 2013, pp. 25-32 (cz. 2). 
[4] Kegel A., Kegel Z.: Przepisy o biegłych sądowych, tłumaczach i specjalistach. Komentarz. Zakamycze, Kraków 2004.

[5] Orzeczenie Sąu Najwyższego z dnia 22 października 1968 roku. SN III CZP 98/68, OSNCP 1969, nr 11, poz. 188 [Supreme Court ruling of 22 October 1968].

[6] Postanowienie Sądu Najwyższego z 10 września 1997 roku. II CKN 309/97, OSNC 1998, nr 2, poz. 30 [Supreme Court order of 10 September 1997].

[7] Rudnicki S.: Własność nieruchomości. Wydawnictwo Prawnicze LexisNexis, Warszawa, 2008.

[8] Rozporzadzenie Ministrów Spraw Wewnętrznych i Administracji oraz Rolnictwa i Gospodarki Żywnościowej z dnia 14 kwietnia 1999 r. w sprawie rozgraniczania nieruchomości. Dz. U. 1999, nr 45, poz. 453 [Regulation of Ministers of Internal Affairs and Administration and the Agriculture and Food Economy on April 14, 1999 on the real estate delimitation. Journal of Laws of 1966, No. 45, item 453].

[9] Śmiałowska-Uberman Z.: Prawo geodezyjne i kartograficzne. Komentarz. Wydawnictwo Gall, Katowice 1999.

[10] Ustawaz dnia 17 maja 1989 roku-Prawo geodezyjne i kartograficzne. Dz. U. 2010, nr 193, poz. 1287 - tekst jednolity z późniejszymi zmianami [Act of 17 May 1989 - Geodesic and Cartographic Law. Journal of Laws of 2010, No. 193, item 1287 - unified text with amendments].

[11] Ustawa z dnia 23 kwietnia 1964 roku - Kodeks cywilny. Dz. U. 1964, nr 16, poz. 93 z późniejszymi zmianami [Act of 23 April 1964 - The Cywil Code. Journal of Laws of 1964, No. 16, item 93 with amendments].

[12] Ustawa z dnia 14 czerwca 1960 roku - Kodeks postępowania administracyjnego. Dz. U. 2013, poz. 267 - tekst jednolity [Act of 14 June 1960 - Code of Administrative Procedure. Journal of Law of 2013, item 267- unified text].

[13] Wyrok Naczelnego Sadu Administracyjnego z 8 listopada 2000 roku. ISA 1986/99 [Judgment of the Supreme Administrative Court of 8 November 2000]

[14] Wyrok Wojewódzkiego Sądu Administracyjnego z 2 września 2008 roku. IV S.A./Wa 980/08 [Judgment of the Regional Administrative Court of 2 September 2008] 